\title{
閉塞性睡眠時呼吸障害と体位の影響
}

\author{
板坂 芳明・山川 浩治・宮崎総一郎 \\ 多田裕之・戸川＼cjkstart清

\section{Obstructive Sleep Dyspnea and Body Position During Sleep} \\ Yoshiaki Itasaka, Koji Yamakawa, Soichiro Miyazaki, \\ Hiroyuki Tada and Kiyoshi Togawa \\ (Akita University School of Medicine)
}

\begin{abstract}
Polysomnography was carried out to evaluate the effect of sleeping posture on obstructive sleep dyspnea. Twelve patients who complained of snoring or obstructive sleep apnea were examined for supine and lateral decubitus sleeping postures. Their mean age was 52.2 years (range 38 to 66 years). Intraesophageal pressure was monitored to assess the respiratory effort, in addition to the measurement of apnea plus hypopnea index and oxygen saturation in polysomnography. In the lateral decubitus position, the apnea plus hypopnea index was decreased (supine, 55.6 \pm 27.0 , lateral, $34.9 \pm 31.3 ; \mathrm{p}<0.01$ ) and the mean decrease in oxygen saturation was improved (supine, $10.7 \pm 4.45 \%$, lateral, $8.05 \pm 2.17 \%$; $\mathrm{p}<0.05)$. In the lateral decubitus position, the amplitude of intraesophageal pressure was decreased but not significantly (supine, $40.0 \pm 19.7 \mathrm{cmH}_{2} \mathrm{O}$, lateral, $33.5 \pm 15.9 \mathrm{cmH}_{2} \mathrm{O}$; N. S.). This suggests that sleep position adjustment may be a useful treatment for obstructive sleep apnea. However, as the amplitude of intraesophageal pressure remained high on the lateral decubitus position, the position changes may not be so benificial for some patients with severe respiratory disturbance during sleep.
\end{abstract}

Key words: obstructive sleep apnea, body position, apnea index, oxygen saturation, intraesophageal pressure

はじめに

睡眠時無呼吸症候群は，睡眠中に主として見 られる無呼吸の型により, 閉塞性, 混合性, 中 枢性に分類されるが，耳鼻咽喉科外来を訪れる 多くの症例は閉塞性である。そして，その主な 閉塞部位は上気道にあると考えられ，また，い びきを含むこれら睡眠時呼吸障害の原因は多種 多様である.さらに，治療法は障害原因の種類， 程度に応じて保存療法, 手術療法と適宜選択さ
れている1) 4).

ところで，一晚の睡眠中に仰臥位，側臥位， あるいは腹臥位と体位を変えることは，しばし ば見られる，そして，睡眠時呼吸障害は睡眠段 階のみならず体位によっても，その状態を変古 る. Cartwright ら 5)6) は, 閉塞性睡眠時無呼吸 症候群の患者に扮いて，側臥位時の apnea index が仰臥位に比べて明らかに減少すると報告 し，体位変換が無呼吸の治療法のひとつとなる 
ことを示唆した。また，睡眠時において側臥位 を維持するようにトレーニングすることを推奖 している.しかし，睡眠時呼吸障害例において， 睡眠時の側臥位が仰臥位に比較して，どの程度 睡眠障害, 呼吸・循環障害の改善をもたらすか, ポリソムノグラフ検査上総合的に検討を加えた 報告は少ない，そこで，最初に睡眠中の体位を 連続的に確実に検出するために，体位計を試作 した。そして，閉塞性睡眠時呼吸障害例におい て，体位が仰臥位と側臥位の場合での， apnea +hypopnea index, 平均無呼吸時間, 睡 眠段階, 酸素飽和度の減少, 食道内圧値等につ いて検討を加えた。 また，主な閉塞および狭窄 が上気道にあると考劣られるので，体位が仰臥 位で, 顔の位置が正面と横向きの場合について も検討を加えた。

\section{対象および方法}

対象は，いびきおよび睡眠時閉塞性呼吸障害 を主訴として当院耳鼻咽喉科外来を訪れた症例 で, ポリソムノグラフ検査を施行しえた12例(男 性 9 例，女性 3 例）である.ここで，6例は終 夜ポリソムノグラフ検査, 残りの 6 例は, 我々 がスクリーニング検査として行っている日中の ポリソムノグラフ検査である7). 今回, 体位に よる比較ということで，まとめて検討を行った. また, 年齢範囲は38歳 66歳で, 平均 52.2 歳で ある。

終夜ポリソムノグラフ検査は午後10時から翌 朝 6 時まで自然睡眠下に，また，日中のポリソ ムノグラフ検查は, 筋弛緩作用の少ないと言わ れる睡眠薬 zopiclone を用いて, 午後 1 時から 4 時まで行った。脳波記録は 10/20 法により, $\mathrm{C}_{3}-\mathrm{A}_{2}, \mathrm{O}_{1}-\mathrm{A}_{2}, \mathrm{C}_{4}-\mathrm{A}_{1}, \mathrm{O}_{2}-\mathrm{A}_{1}$ の単極導出とした. また, 眼球運動, 願筋筋電図, ストレンゲージ による胸・腹の運動, サーミスタによる呼吸曲 線を合わせて脳波計にて記録した。ささらに，経 皮的酸素 -二酸化炭素分圧值, 酸素飽和度, 呼 気酸素・二酸化炭素濃度, インピーダンス方式 に上る換気量, 呼吸数, 心拍数, そして食道内 圧值をバルーン法にて測定しリニアコーダに
連続記録した。また，検査中の体位および顔の 位置は，圧電素子扣よび水銀スイッチを用いた 体位計にて，連続記録した，顔の位置において 横向きとは，仰臥位において顔が正面から20度 以上傾いた時とした．検定は paired t-test を用 いた.

\section{結果}

表 1 は, 12症例の年齢, body mass index, 仰臥位および側臥位の全睡眠時間を示している。 仰臥位に拈ける全睡眠時間は顔の位置が正面 （12例）の時平均 134.5 分, 横向き（8例）の時 平均55.6分であった。 また，側臥位（8例）に 拈ける全睡眠時間の平均值は，120.2分であっ た. 次に，それぞれの場合について述べる。

1. 睡眠中の体位が仰臥位で, 顔の位置が正 面と横向きの場合の比較（8 例）

図 1 に，それぞれの場合に拈ける apnea+ hypopnea index, 無呼吸時に护ける酸素飽和度 の減少の平均值 (平均減少値), 食道内圧値 (5 分ごとに食道内圧値の絶対值の最大值を求め, その平均值で代表した。）を示している. apnea +hypopnea index に执いて, 顔の位置が正面 の場合, $60.7 \pm 24.3$, 横向きの場合, $65.8 \pm 20.6$ となり有意差は見られなかった。 また, 酸素飽 和度の平均減少值は, 正面の場合 $9.29 \pm 5.46 \%$, 横向きの場合 $8.77 \pm 4.73 \%$, 食道内圧值は, 正 面の場合 $33.9 \pm 20.1 \mathrm{~cm} \mathrm{H} \mathrm{H}_{2} \mathrm{O}$, 横向きの場合 $34.9 \pm 20.5 \mathrm{~cm} \mathrm{H}_{2} \mathrm{O}$ となり, それぞれ有意な差 は見られなかった。

2. 睡眠時の体位が仰臥位と側臥位の場合の 比較 ( 8 例)

図 2 は, 閉塞性睡眠時無呼吸症候群の 1 症例 で, 59歳, 男性の例である. 上段に睡眠中の体 位の状態を示している. apnea + hypopnea index は仰臥位で57.9, 側臥位で 2.42 , 酸素飽和 度の平均減少值は仰臥位で $7.98 \%$, 側臥位で 6 \%となり，それぞれ明らかな改善を示した。し かし, 食道内圧值は仰臥位で $18.9 \mathrm{~cm} \mathrm{H}_{2} \mathrm{O}$, 側 臥位で $18.1 \mathrm{~cm} \mathrm{H} \mathrm{H}_{2} \mathrm{O}$ となり, 大きな変化は見 られなかった。 
表 1 閉塞珄睡眠時呼吸障害を示した12症例の年齡, BODY MASS INDEX, 全睡眠時間

\begin{tabular}{|c|c|c|c|c|c|c|}
\hline \multirow{3}{*}{ 症＼cjkstart例 } & \multirow{3}{*}{ 性 別 } & \multirow{3}{*}{ 年 秢 } & \multirow{3}{*}{$\begin{array}{l}\text { Body mass } \\
\text { index }\left(\mathrm{kg} / \mathrm{m}^{2}\right)\end{array}$} & \multirow{2}{*}{\multicolumn{2}{|c|}{\begin{tabular}{|c} 
仰臥位の全睡眠時間（分） \\
顔の位置
\end{tabular}}} & \multirow{3}{*}{$\begin{array}{c}\text { 側臥位の } \\
\text { 全睡眠時間 (分) }\end{array}$} \\
\hline & & & & & & \\
\hline & & & & 正 面 & 横向き & \\
\hline 1 & 女 & 60 & 31.3 & 84.1 & 128.6 & - \\
\hline 2 & 女 & 66 & 21.8 & 145.9 & 21.1 & - \\
\hline 3 & 女 & 59 & 23.7 & 108.2 & 18.4 & - \\
\hline 4 & 男 & 43 & 33.2 & 170.2 & 20.6 & - \\
\hline 5 & 男 & 38 & 29.9 & 121.0 & 2.6 & 13.8 \\
\hline 6 & 男 & 35 & 31.4 & 17.9 & 16.1 & 164.7 \\
\hline 7 & 男 & 54 & 26.1 & 203.6 & 50.3 & 83.2 \\
\hline 8 & 男 & 59 & 27.6 & 63.3 & 187.2 & 148.7 \\
\hline 9 & 男 & 66 & 24.4 & 94.5 & - & 103.3 \\
\hline 10 & 男 & 56 & 24.0 & 141.4 & - & 94.1 \\
\hline 11 & 男 & 39 & 28.4 & 156.7 & - & 265.3 \\
\hline 12 & 男 & 51 & 26.1 & 306.7 & - & 88.3 \\
\hline 平 & & 52.2 & 27.3 & 134.5 & 55.6 & 120.2 \\
\hline 標準偏差 & & 10.9 & 3.58 & 73.9 & 66.4 & 74.2 \\
\hline
\end{tabular}

仰卧位

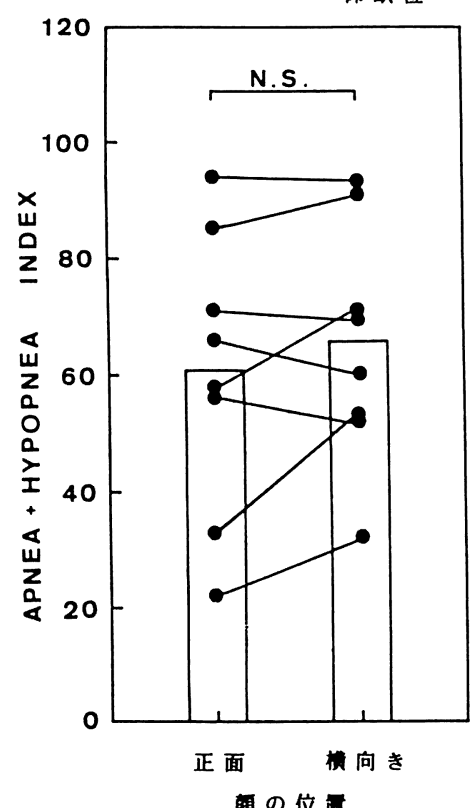

仰臥位

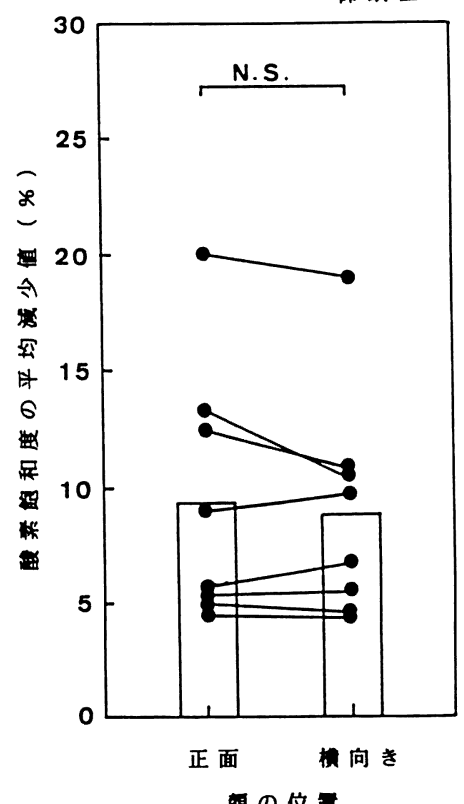

仰卧

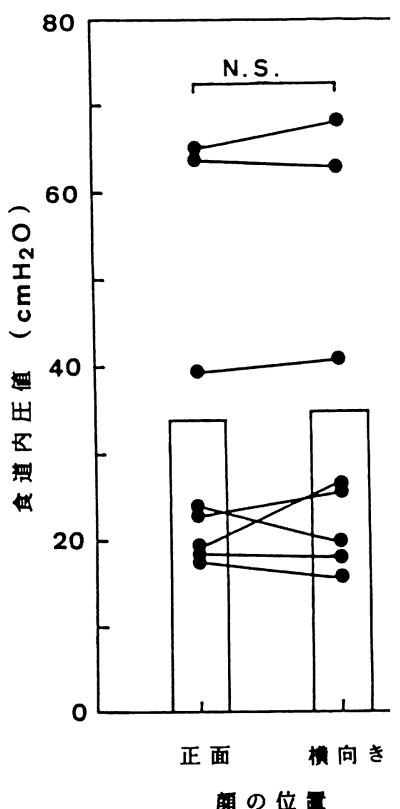

図 1 体位が仰臥位で, 顔の位置が正面と横向きの場合の APNEA+HYPOPNEA INDEX, 酸素 飽和度の平均減少値, 食道内圧値 
次に, 8 症例に拈ける apnea +hypopnea index, apnea index, hypopnea index, を仰臥位 および側臥位の場合について示す(図 3 ). apnea +hypopnea index は仰臥位で55.6 27.0 , 側 臥位で34.9 31.3 となり $1 \%$ で有意に差が見ら れた。 また，その中で, apnea indexは仰臥位

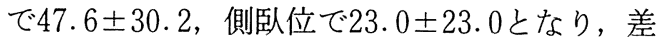
がさらに明らかになった。しかし, hypopnea

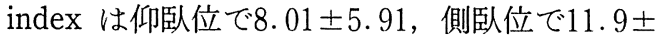
13.4となり有意な差は見られなかった。特に, apnea +hypopnea index の大きい症例において は，側臥位になると， apnea index が減少する が, hypopnea index が増加する場合も見られ た。 また, 閉塞型の平均無呼吸時間は, 仰臥位

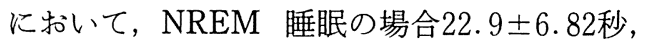
REM 睡眠の場合 $33.7 \pm 4.17$ 秒, 側臥位におい

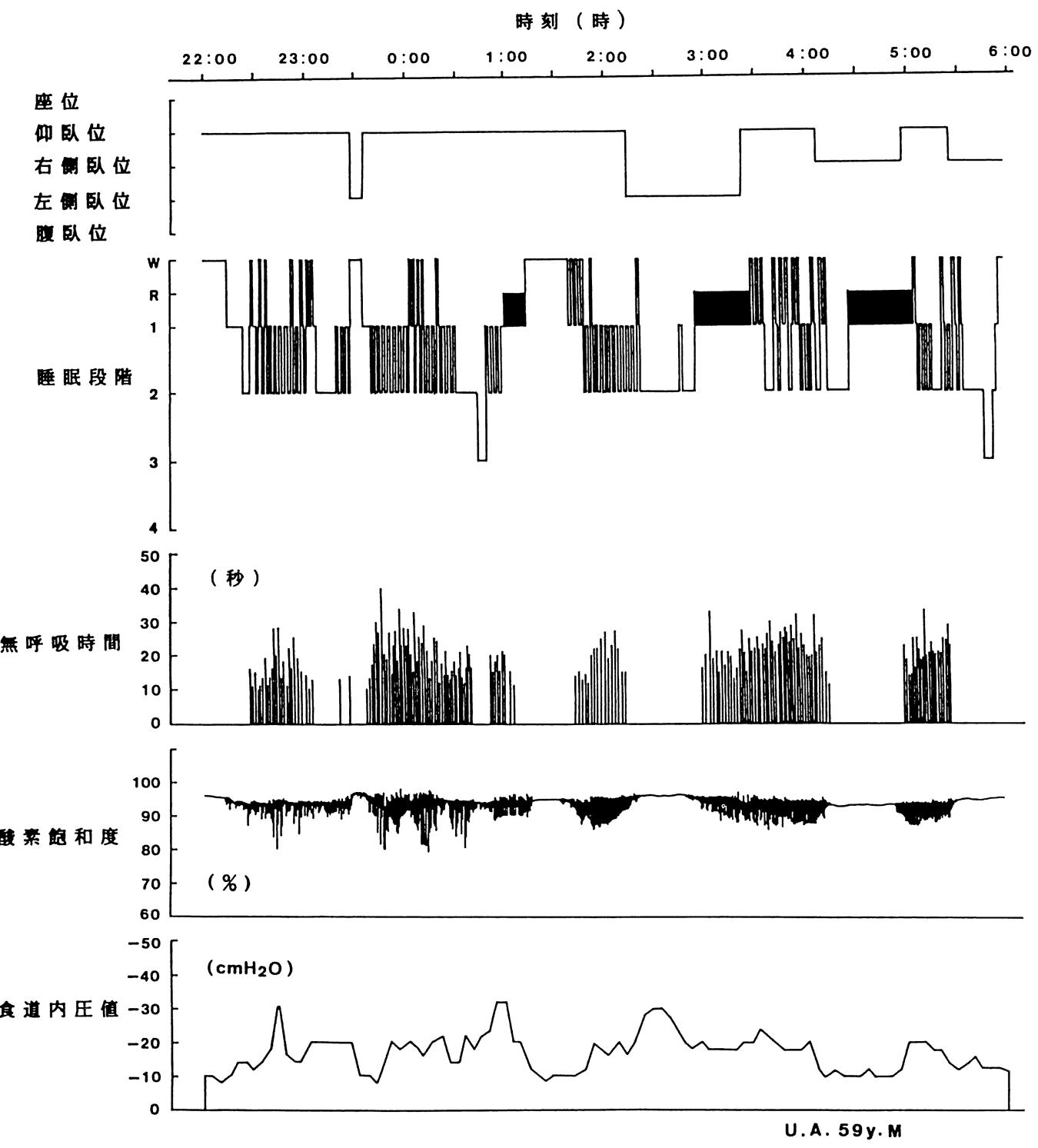

図 2 閉塞性睡眠時無呼吸を示した 1 症例の睡眠経過図 
て，NREM 睡眠21.5土5.52秒， REM 睡眠27.0 土4.52秒となり側臥位で短縮傾向を示したが， 有意差は見られなかった。図 4 は，それぞれの 体位に括ける睡眠段階出現率を示している. 図 の様に仰卧位に比較して, 側臥位においては覚 醒, stage 1，2 の浅睡眠が少なくなり, stage 3, 4 の深睡眠および REM 睡眠が多くなる傾向 が見られた。図 5 は, 無呼吸時に括ける酸素飽 和度の平均減少值を仰臥位と側臥位別に示して ある. 酸素飽和度の平均減少值は，仰臥位にお

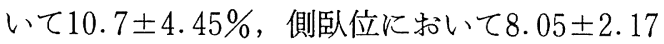
\%となり有意に差が見られた。次に，睡眠中の 食道内圧值を仰臥位，側臥位別に示す（図 6). 食道内圧值は，仰臥位に打いて $40.0 \pm 19.7 \mathrm{~cm}$ $\mathrm{H}_{2} \mathrm{O}$ ，側臥位において $33.5 \pm 15.9 \mathrm{~cm} \mathrm{H}_{2} \mathrm{O}$ とな り，側臥位時の食道内圧值は仰臥位に比較して， 小さい傾向を示したが有意な差が見られなかっ た。

\section{考察}

閉塞性睡眠時呼吸障害症例において，睡眠中 の無呼吸拈よびいびきが睡眠中の体位によって
影響を受けることは経験的に良く知られている ことである. Mcevoy ら ${ }^{8)}$ は, 閉塞性睡眠時無 呼吸症候群の症例に扮いて，仰臥位から座位に 60 度体位を変化させることにより，夜間の覚醒 回数, 閉塞性無呼吸の減少と低酸素血症の改善 を報告している。しかし，一般に，成人の場合 睡眠時の体位は，仰臥位および側臥位が主と考 えられる、したがって，今回睡眠時における仰
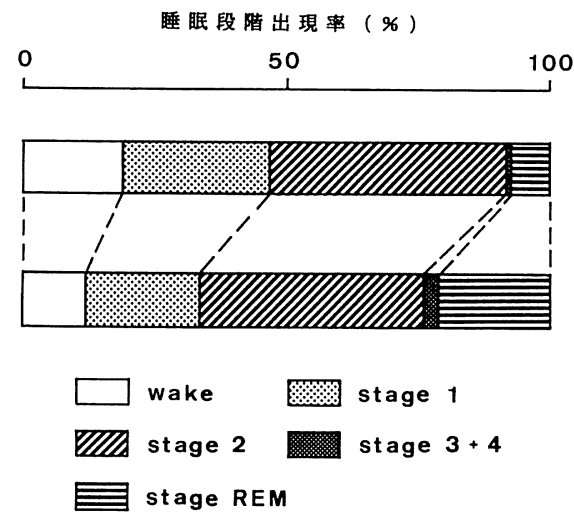

図 4 仰臥位および側臥位での睡眠段階出現率

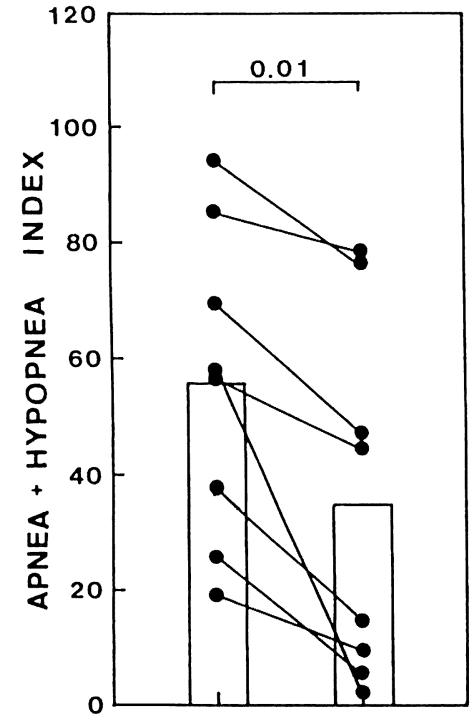

印卧位略位

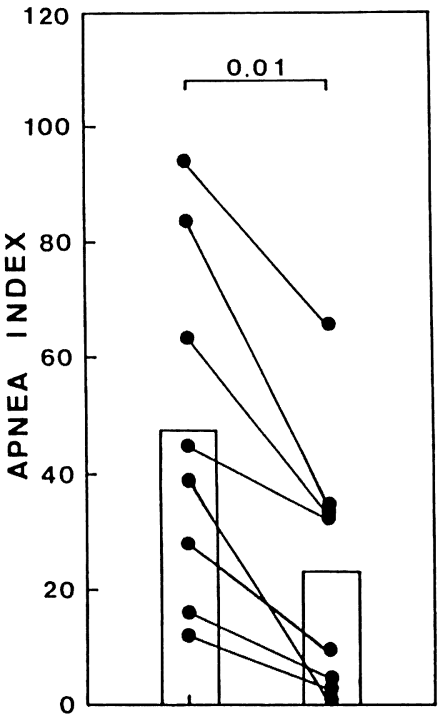

印臥位濑卧位

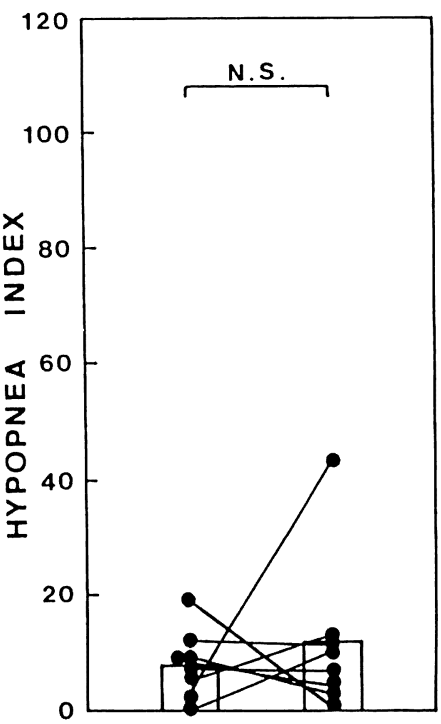

仰卧位侀卧位

図 3 仰臥位拈よび側臥位での apnea+hypopnea index, apnea index, hypopnea index 
臥位と側臥位について検討を加えた。また，対 象にしたのは閉塞性の睡眠時呼吸障害例であり， その狭窄あるいは閉塞が主に上気道にあると推 測されるため, 最初に体位が仰臥位で, 顔の位 置が正面の時と横向きの時について比較した． しかし，顔が正面から横向きになった直後の数 分間は，呼吸障害が改善する場合も見られたが， その後, 睡眠時呼吸障害は正面の時と同じ程度 に戻り, 顔が正面の時と横向きの時では差は見 られなかった。これは，今回顔が正面から20度 以上傾いた時を横向きとして検出したが，今後 横向きの程度についても検討する必要があると 思われる。

Lerner $ら^{9)}$ は，閉塞性睡眠時無呼吸症候群の 患者に括いて, 側臥位時の apnea+hypopnea index が仰臥位に比較して明らかに減少し，ま た，側臥位は睡眠構築にも改善をもたらすと述 ベている、また，ポリソムノグラフ検査に㧤い

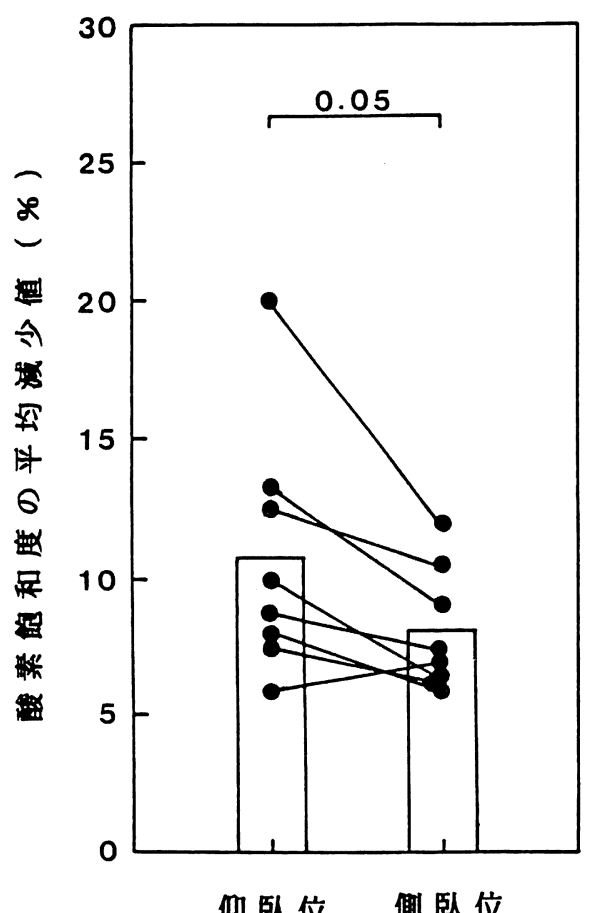

図 5 仰臥位および側臥位での酸素飽和度 の平均減少值
て体位検出の必要性を示唆している. 一方, George $5^{10)}$ は, 閉塞性睡眠時無呼吸症候群の 患者に拈いて，仰臥位と側臥位での apnea +hypopnea index について睡眠段階を考慮にいれ検 討した結果, 非常に肥満の患者においては, 側 臥位になることが，以前に言われている様に適 切なものではないと報告した。また，垣鍔11) は，いびきは睡眠全体を通してみると側臥位と 仰臥位で著明な差は認められなかったと述べて いる.

我々の研究では, 側臥位時の apnea+hypopnea index および apnea index は, 仰臥位に比較し て明らかな改善が見られ, apnea+hypopnea index が仰臥位時に比較して半分以下になった のは 8 例中 4 例であった。 しかし，障害の大き い症例に执いては apnea+hypopnea index の 改善する割合が小さかった。ささらに，8例中 3 例に执いて, apnea が減少するが hypopnea が

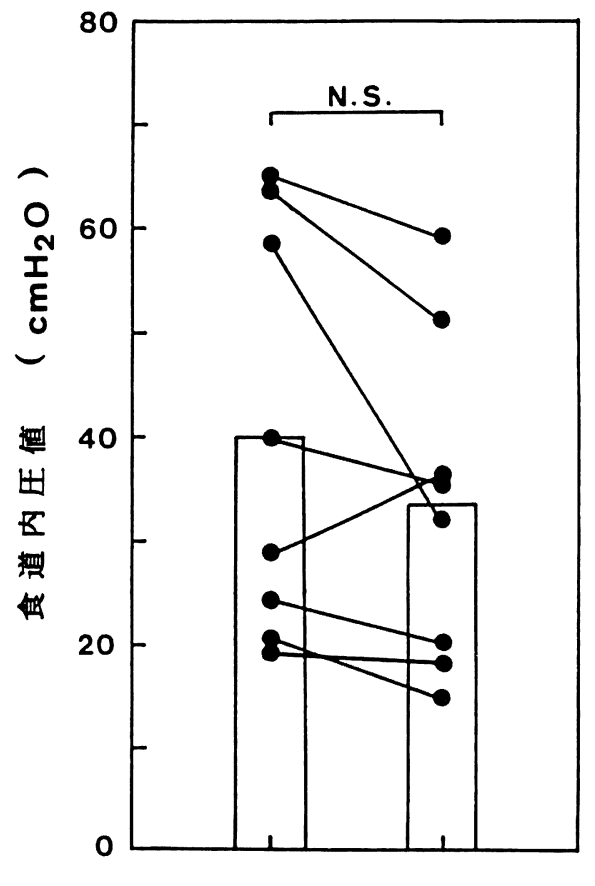

仰臥位倒臥位

図 6 仰臥位および側臥位での食道内圧值 
逆に増加する症例も見られた．次に，睡眠段階 出現率を見ると，側臥位においては，仰臥位と 比較して浅睡眠が少なくなり，深睡眠扣よび REM 睡眠が多くなる傾向が見られた。 また， 無呼吸時に打ける酸素飽和度の平均減少值は, 側臥位に执いて，仰臥位に比較して有意に小さ かった。ところで，側臥位に括ける食道内圧值 は，仰臥位に比較して小さくなる傾向は見られ たが有意差はなく，依然として狭窄が残ってい る例が多かった．また，いびきに関しても依然 として残っている症例もあった。

戸川ら12) は，いびきおよび閉塞性無呼吸の 発生には，上気道の形態的異常による狭窄に加 えて，睡眠時における上気道構成諸筋の筋の緊 張低下，扣よび仰臥位での重力の影響による軟 口蓋および舌根の後方への沈下が強く関与して いると述べている。ここで，apnea の減少は， 側臥位になることにより軟口蓋あるいは舌根の 咽頭後壁への沈下がある程度防止されたことが 主な理由と考兄られる。一方，食道内压值に明 らかな減少が見られなかったことから，狭窄が 側臥位に怙いてもまだ残っていると思われる. したがって，側臥位で睡眠をとることは，閉塞 性無呼吸に対する最も簡便な治療法のひとつで あると考えられるが，側臥位に打いても狭窄が 依然として残る例があり，特に中等度以上の閉 塞性睡眠時呼吸障害を示す症例には，外科的治 療を含めた何等かの積極的な治療が望まれる。

\section{まとめ}

閉塞性睡眠時呼吸障害例に対してポリソム， グラフ検查を行い，仰臥位および側臥位におけ る睡眠時呼吸障害の程度について比較検討し， 次の様な結果を得た。

1 ) 側臥位における apnea + hypopnea index および apnea index は仰臥位に比較して有意に 小さかった. しかし, hypopnea index のみで は差は見られなかった。

2 ）側臥位に拉いては，仰卧位に比較して浅 睡眠が少なく，深睡眠技よび REM 睡眠が多い 傾向が見られた.
3 ）側臥位に打ける酸素飽和度の平均減少值 は，仰臥位に比較して有意に小さかった。

4 ）側臥位における食道内圧值は，仰卧位に 比較して小さい傾向を示したが有意な差は見ら れなかった。

\section{参考文献}

1）戸川 清, 宮崎総一郎, 山川浩治, 他 : 睡眠時 無呼吸症候群の検査之診断. 耳喉頭頸 $61: 681$ $\sim 687,1989$.

2）戸川 清, 宮崎総一郎, 山川浩治 : 閉塞性睡眠 時無呼吸症候群の治療. 日気食会報 $40 ：$ 409 415, 1989.

3）藤田史朗：アメリカに扣ける睡眠時無呼吸症候 群の研究と治療の現況. 精神医学 $27: 207 \sim 217$, 1985.

4）杉田義郎, 手島愛雄, 西村信哉, 他：睡眠時無 呼吸症候群の物理的, 外科的治療. 臨床精神医 学 $14: 1797 \sim 1804,1985$.

5) Cartwright RD : Effect of sleep position on sleep apnea severity. Sleep $7: 110 \sim 114,1984$.

6) Carwright RD, Lloyd S, Lilie J, et al : Sleep position training as treatment for sleep apnea syndrome; a preliminary study. Sleep $8: 87$ $\sim 94,1985$.

7) Itasaka $Y$, Yamakawa $K$, Miyazaki S, et al : Daytime polysomnography with zopiclone for the screeing test of respiratory disturbance during sleep. J J Psychiatr Neurol $44: 824,1990$.

8) Mcevoy RD, Sharp DJ and Thornton AT : The effects of posture on obstructive sleep apnea. Am Rev Respir Dis 133 : 662 666, 1986.

9) Lerner SA and Cecil MA : The effect of sleeping posture on obstructive sleep apnea. Chest $26: 327,1984$

10) George CF, Millar TW and Kryger MH : Sleep apnea and body position during sleep. Sleep $11: 90 \sim 99,1988$.

11）坦鍔典也：躰の睡眠深度別発現頻度と音源に関 する研究 一斯の研究一. 耳鼻臨床 補 $39: 1$ 39, 1990.

12）戸川 清, 宮崎総一郎, 山川浩治, 他：いびき JOHNS $6:$ :66 70, 1990 .

別刷請求先：板坂芳明 干010 秋田市本道一丁目 1-1

秋田大学医学部耳鼻咽喉科学教室) 